\title{
EFFECT OF THE EGYPTIAN SAHARA SAND VIPER VENOM ON HUMAN BREAST CANCER: AN IN VITRO STUDY
}

\author{
By \\ ABIR A. EL-FIKY ${ }^{1}$, AHMED ELDOUSOUKY ${ }^{2}$, \\ AND DINA M. ELKHASHAB ${ }^{3}$
}

Anti-venom Research, (VACSERA), Dokki ${ }^{1}$ and Faculty of Biotechnology, October University for Modern Science and Arts University, $6^{\text {th }}$ of October $^{2}$, and Department of Clinical Pathology, National Cancer Institute, Cairo University ${ }^{3}$, Egypt ( ${ }^{*}$ Correspondence: elfikyabir@gmail.com)

\begin{abstract}
Cancer is a major health problem which is considered as one of the most reasons of death worldwide. Breast cancer is a second cause of women death and estimated to have 2.1 million new cases. Traditional treatment of cancer based on different clinical approaches is included surgery, chemotherapy, radio therapy, hormone therapy and combination therapy which affect both cancer and normal cells. The present study investigated the anticancer potential of Cerastes vipera venom in comparison with Cisplatin drug on MDA-MB-231 breast cancer cell line. Cytotoxicity activity of tested material was evaluated using MTT assay. Cell cycle arrest was performed using propidium iodine DNA staining. Apoptotic detection was determined using annexin V-FTIC and for the detection of the genes Caspase 3, Caspase 8 \& Caspase 9 were determined by ELISA. The $C$. vipera venom, Cisplatin and PLA2 had IC50 as 3.4, 10.3, 35.1 $\mu \mathrm{g} / \mathrm{mL}$ with MDA-MB-231 cell line respectively. Cell cycle has arrest of cells in G2/M of $C$. vipera venom and PLA2. Tested venoms have apoptotic effect against MDA-MB-231 cell line through elevation of Caspase 3, Caspase 8 \& Caspase 9 genes.
\end{abstract}

Keywords: Breast cancer, Snake venom, MDA-MB-231, Cerastes vipera venom, Phospholipase A2 (PLA2), and Cisplatin.

\section{Introduction}

Breast cancer in women is a major health burden. It is the most common cause of cancer death among women impacting 2.1 million female every year (WHO, 2018). In Egypt, breast cancer standardized in a second rank. The incidence rate of breast cancer was calculated and estimated that approximately $38.7 \%$ were among women and $21.6 \%$ among both sexes. National Cancer Registry Program (NCRP) estimated that a threefold increase of incidence rate of in 2050 relative to 2013 (Ibrahim et al, 2014). Nowadays, treatment of Breast cancer is a fundamental challenge to the medical world. Present strategies of treatment are very expensive and have several side effects. Patient has to suffer physically and mentally. Some of the elements of snake venom reason retardation of growth of cancerous cells. Due to its therapeutic activity, potency and availability, snake venom may also be a fundamental nominee for the remedy in the future for many diseases and disorders. Viewing and analyzing with futuristic prospectus in the pharmaceutical world, snake venom could open the doorways for new generation of the medicines and research for treatment of Breast cancer (Bazaa et al, 2005). Cerastes vipera venom contains a complex mixture of enzymes including phospholipaseA2 and proteases, L-amino acid oxidase, C-type lectin and Disintegrins. Especially PLA2 which is considered the main component of the vipera venom causes hydrolysis of the membrane phospholipids which induces the release of lysophospholipids and fatty acids resulting in the pharmacological effects within cells such as membrane damage, disruption of membrane-bound protein and functional disturbances of the cellular cascade, and liberation of some bioactive products (El-Aal et al, 2017). Snake venom inhibited cell proliferation and promotion of cell death by means of unique means: induction of apoptosis in cancer cell, increasing 
$\mathrm{Ca} 2+$ influx; inducing cytochrome $\mathrm{C}$ release; decreasing or increasing the expression of proteins that control cell cycle; inflicting damage to cell membranes. Snake venoms include a significant array of components, the majority of which act on the peripheral nervous system for killing or immobilizing prey (Vyas et al, 2013).

The study aimed to improve a new agent from snake venoms as useful in cancer therapy especially breast cancer

\section{Material and Methods}

Cisplatin was diluted in RPMI-1641 media $1 \mathrm{mg} / 1 \mathrm{~mL}$ (BioWhittaker ${ }^{\mathrm{TM}}$ Classical Media, Lonza) to prepare test concentrations. Cerastes vipera venom or (Egyptian Sahara sand viper) venom (C.v.), phospholipase A2 (PLA2) were kindly supplied from ANDI Center, VACSERA. They were dissolved in $1 \mathrm{mg} / 1 \mathrm{~mL}$ sterile distilled water and sterilized using $0.22 \mathrm{~m}$ disposable syringe filter (Millipore-USA) and serially diluted in the RPMI-1641 media (BioWhittaker ${ }^{\mathrm{TM}}$ Classical Media, Lonza). MDA 321 (human breast cancer cell line) was supplied from American Type Culture Collection (ATCC). Tryp$\sin 0.25 \% \%$ was provided by VACSERACell Culture Unit, Egypt. Cells were seeded at a density of $2 \times 10^{5} / \mathrm{ml}$ and routinely cultured in RPMI-1641 medium in tissue culture flasks (Grien-er, Germany).

Cytotoxicity by using colorimetric assay (MTT): MDA 321cell line was seeded in 96well tissue culture plate with $100 \mu \mathrm{L}$ of the RPMI medium. $200 \mu \mathrm{L}$ tested materials serial dilution using two fold dilutions. Plates were incubated with the venom concentrations of for $24 \mathrm{~h}$ at $37^{\circ} \mathrm{C}$. Plates were read using ELISA reader at wave length $570 \mathrm{~nm}$ and the absorbance was correlated with cell number. Cytotoxic effects of the tested venom on the MDA 321 cell lines were expressed as $\mathrm{IC}_{50}$ value. Inhibitory concentration $\left(\mathrm{IC}_{50}\right)$ was assessed by the Masterplex software (2010).

Flow cytometry cell cycle analysis using Propidium iodide DNA staining: For cell cycles analyzed by FACS, cell line was seeded in DMEM with 10\% FBS, fixed in cold $70 \%$ ethanol on 6-well plates and then allowed to attach overnight. While, the vortexing, pellet was added drop wise. All cells were fixed for $30 \mathrm{~min}$ at $4^{\circ} \mathrm{C}$ and minimized clumping. After fixation, cells were washed in PBS and spun at $850 \mathrm{~g}$ in a centrifuge. Supernatant was discarded especially after ethanol spinning out. The cells were treated with ribonuclease I $(100 \mathrm{mg} / \mathrm{ml}$ stock solution). $50 \mu \mathrm{l}$ of $100 \mu \mathrm{g} / \mathrm{ml}$ sock of RNase was added to ensure that only the DNA and not RNA were stained. $200 \mu$ propidium iodide was added $(50 \mu \mathrm{g} / \mathrm{ml}$ stock solution).

Apoptosis analysis by using Annex in VFITC assay: $1-5 \times 10^{5}$ cells were collected by centrifugation and were re-suspended in $500 \mu 1$ of $1 \mathrm{X}$ Binding Buffer. $5 \mu \mathrm{l}$ of Annexin V-FITC \& $5 \mu \mathrm{l}$ of propidium iodide (PI 50 $\mathrm{mg} / \mathrm{ml}$ ) were added. Incubation was performed at room temperature for $5 \mathrm{~min}$ in the dark. Annexin V-FITC binding was analyzed by flow cytometry $(E x=488 \mathrm{~nm} ; \mathrm{Em}=$ 530nm) using FITC signal detector and PI staining by phycoerythrin emission signal detector. For adherent cells, they were gently trypsinized and washed once with serumcontaining media before incubation with Annexin V-FITC. Stained cells were analyzed for percentage of apoptotic cells by Partec flow cytometer and FloMax software. Casps 3, 8, \& 9 were detected by ELISA using anti-human caspase coating antibody adsorbed onto micro-wells. Human caspase present in the sample or standard binds to antibodies adsorbed to the micro-wells. The polyclonal detection antibody (rabbit) binds to human caspase captured by the first antibody. Following incubation unbound detection antibody was removed during a wash step. Anti-rabbit-IgG-HRP was added and binds to the antibody detection. After incubation unbound anti-rabbit-IgG-HRP was removed during a wash step, and substrate solution reactive with HRP is added to the wells. A colored product is formed in proportion to the amount of human Caspase- 9 present in the sample or standard. The reac- 
tion is terminated by addition of acid and absorbance was measured at $450 \mathrm{~nm}$. The standard curve was prepared from human caspase standard dilutions and human caspase concentration determined.

Statistical analyses: Experiments were carried out in triplicate unless specified. Results were represented as mean \pm SEM. Analysis was done using unpaired Student's t test. Multiple groups were compared by one-way ANOVA with Dennett's post-test. P value < 0.05 was considered significant $\& \mathrm{p}<0.01$ was highly significant.

\section{Results}

The results were shown in tables $(1,2,3,4,5)$ and figures $(1,2,3,4,5$ \& 6$)$

Table 1: Cerastes vipera venom against Cisplatin on inhibitory effect on MDA-MB-231 breast cancer cell line.

\begin{tabular}{|c|c|c|}
\hline \multirow{2}{*}{ Series } & \multirow{2}{*}{ Sample code } & IC50uM \\
\hline & & MDA-MB-231 \\
\hline 1 & Snake venom & $3.480960187 \pm 0.17$ \\
\hline 2 & PLA2 & $35.10247153 \pm 1.6$ \\
\hline 3 & Cisplatin & $10.36281351 \pm 0.52$ \\
\hline
\end{tabular}

Table 2: Effect of cell cycle concentration on MDA-MB-231 cell line by different samples

\begin{tabular}{|c|l|c|c|c|c|l|}
\hline \multicolumn{3}{|c|}{ Sample data } & \multicolumn{4}{c|}{ Results } \\
\hline Series & Sample code & \%G0-G1 & $\% \mathrm{~S}$ & $\% \mathrm{G} 2-\mathrm{M}$ & $\%$ Pre-G1 & Comment \\
\hline 1 & Snake venom & 23.76 & 19.73 & 56.51 & 27.52 & PreG1apoptosis\&Cell growth arrest@G2/M \\
\hline 2 & PLA2 & 43.88 & 25.06 & 31.06 & 13.25 & PreG1apoptosis\&Cell growth arrest@G2/M \\
\hline 3 & Cisplatin & 27.82 & 17.59 & 54.59 & 24.71 & PreG1apoptosis\&Cell growth arrest@G2/M \\
\hline 4 & Cont cancer cell & 61.54 & 28.29 & 10.17 & 1.41 & \\
\hline
\end{tabular}

Table 3: Evolution of viper venom, PLA2 and Cisplatin on MDA-MB-231 cell line.

\begin{tabular}{|c|c|c|c|c|c|}
\hline \multirow[b]{2}{*}{ Series } & \multirow[b]{2}{*}{ code } & \multicolumn{3}{|c|}{ Apoptosis } & \multirow[b]{2}{*}{ Necrosis } \\
\hline & & Total & Early & Late & \\
\hline 1 & Viper venom & 27.52 & 7.58 & 16.67 & 3.27 \\
\hline 2 & PLA2 & 13.25 & 4.39 & 6.25 & 2.61 \\
\hline 3 & Cisplatin & 24.71 & 5.93 & 14.85 & 3.93 \\
\hline 4 & Cont & 1.41 & 0.76 & 0.28 & 0.37 \\
\hline
\end{tabular}

Table 5: Gene expression level of Casp3 in treated cells and untreated cells

\begin{tabular}{|c|l|c|c|}
\hline \multirow{2}{*}{ Series } & \multirow{2}{*}{ Cpd. code. } & \multicolumn{2}{|c|}{ Caspase3 } \\
\cline { 3 - 4 } & & \multicolumn{2}{|c|}{ MDA-MB-231 } \\
\cline { 3 - 4 } & & $\mathrm{Pg} / \mathrm{ml}$ & Fld \\
\hline 1 & Viper venom & $476.9 \pm 19.6$ & 7.47 \\
\hline 2 & PLA2 & $225.1 \pm 11.02$ & 3.52 \\
\hline 3 & Cisplatin & $347.4 \pm 14.6$ & 5.44 \\
\hline 4 & Cont & $63.83 \pm 3.4$ & 1 \\
\hline
\end{tabular}

Table 6: Gene expression level of Casp8 in treated cells and untreated cells

\begin{tabular}{|l|l|l|c|c|}
\hline \multicolumn{2}{|c|}{ Compound } & \multicolumn{3}{|c|}{ Results } \\
\cline { 3 - 5 } & & \multicolumn{3}{|c|}{ MDA-MB-231 } \\
\hline series & Cpd. code. & Assay conc. uM & Caspase8 \\
& & & $0.6861 \pm 0034$ & 3.31 \\
\hline 1 & Snake venom & & $0.5004 \pm 0.02$ & 2.41 \\
\hline 2 & PLA2 & & $0.612 \pm 0.03$ & 2.95 \\
\hline 3 & Cisplatin & & $0.2068 \pm 0.01$ & 1 \\
\hline 4 & Cont & & \\
\hline
\end{tabular}

Table 7: Gene expression level of Casp ( in treated cells and untreated cells

\begin{tabular}{|l|l|c|c|}
\hline \multicolumn{2}{|l|}{ Sample } & \multicolumn{2}{|c|}{ Results } \\
\hline \multirow{2}{*}{ Series } & \multirow{2}{*}{ Cpd.code } & \multicolumn{2}{|c|}{ Caspase $9 \mathrm{ng} / \mathrm{ml}$} \\
\cline { 3 - 4 } & & MDA-MB-231 & fld \\
\hline 1 & Snake venom & $30.18 \pm 1.42$ & 18.89 \\
\hline 2 & PLA2 & $14 \pm 0.66$ & 8.76 \\
\hline 3 & Cisplatin & $23.38 \pm 1.13$ & 14.63 \\
\hline 6 & Cont & $1.597 \pm 0.05$ & 1 \\
\hline
\end{tabular}




\section{Discussion}

There was a significant advancement in cancer therapy investigation which involved synthesis of peptides and proteins specific for oncoproteins (Chaubey, 2014). Subsequently, after realizing the potential of medical use of peptides and proteins as anticancer effects, several proteins and peptides are isolated from animal origin. According to Chaisakul et al. (2016) venoms of several animal species including snake and scorpion as well as their biochemical derivatives have investigated in the potential therapeutic tool as anticancer effect. Regarding to the previous studies of the complexity and cytotoxicity of bioactive components of animal venoms, they have characterized through highly levels of specificity leads to induce various types of tumor cells by interfering with the mechanisms of hallmarks in cancer development (Gomes et al, 2010; Alyan et al, 2014; Abdel-Aziz et al, 2017). PLA2 are enzymes that catalyse the hydrolysis of sn-2 fatty acyl ester bonds of sn-3 phosphoglycerides, liberating free fatty acids and lysophospholipids. PLA2 are the most abundant protein found in vipers snake venoms, some venom PLA2s show antitumor by mechanism independent of their enzymatic activity (Zouari-Kessentini et al, 2013). Phospholipases A2 (PLA2) is enzymes of high medical scientific interest due to their involvement in a large number of human inflammatory diseases. PLA2 constitute a diverse family of enzymes which catalyzed the hydrolysis of the sn-2 ester bond in glycerophospholipids and exhibit a wide range of physiological and pathological effects. The ubiquitous nature of PLA2 highlights the important role they play in many biological processes, as cell signaling and cell growth, including the generation of proinflammatory lipid mediators such as prostaglandin and leukotrienes, regulation of lipid mediators. The activity and expression of several PLA2 isoforms are increased in several human cancers, suggesting that these enzymes have a central role in both tumor devel- opment and progression and can be targets for anti-cancer drugs. On the other hand, the some PLA2 isolated from Viperidae venoms are capable to induce anti-tumoral activity. In summary, PLA2 from snake venoms can be a new class of anticancer agents and provide new molecular and biological insights of cancer development (Rodrigues et al, 2009). However, because of drug resistance and numerous undesirable side effects such as severe kidney problems, allergic reaction, decrease immunity to infections, gastrointestinal disorders, hemorrhage, and hearing loss especially in younger patients, other platinum-containing anti-cancer drugs such as carboplatin, oxaliplatin and others, have also been used. Furthermore, combination therapies of cisplatin with other drugs have been highly considered to overcome drugresistance and reduce toxicity, Its mode of action has been linked to its ability to crosslink with the purine bases on the DNA; interfering with DNA repair mechanisms, causing DNA damage, and thus inducing apoptosis in cancer cells (Shaloam and Paul Bernard, 2014). Salvesen and Dixit (1997) and Cummings et al. (2000) found that apoptosis is a controlled type of cell death that energydependent leading to cell shrinkage, chromatin condensation, membrane budding, hosphatidylserine externalization, and activation of a family of cysteine proteases called caspases. Caspase activation is the key step in the apoptosis beginning, and several stimuli activate caspases, including those that activate plasma membrane death receptors (caspase 8 ) and cause mitochondrial dysfunction (caspase 9). Caspases are either initiators or executioners of apoptosis. Initiator caspases include caspases $8 \& 9$, and activation of the caspases result in downstream activation or executioner caspases such as caspases 3 and 7 (Salvesen and Abrams, 2004). Executioner caspases are accountable in many of the biochemical characteristics of apoptosis, including cleavage and activation of poly (ADPribose) polymerase and of the inhibitor of caspase activator domain protein that leads 
to DNA fragmentation.

In the present study, evaluation of cytotoxicity on $M D A-321$ cells treated with $C v$ venom for $24 \mathrm{hr}$, was $3.4 \mu \mathrm{g} / \mathrm{mL}$. This nearly agreed with Yalcin et al. (2014) and Bradshaw et al. (2016) who found that inhibitory concentration of Viperidae snake venoms toward $M C F-7$ cells was after $24 \mathrm{~h}$ incubation evaluated $4.2 \mu \mathrm{g} / \mathrm{mL}$. But, the result disagreed with Gomes et al. (2015) who found that cytotoxicity was $35.5 \mu \mathrm{g} / \mathrm{mL}$ in case of russets viper on leukemic cancer cells after $48 \mathrm{hr}$ of treatment. This difference may be due to species difference and/or cell line used. Evaluation of PLA2 cytotoxicity on MDA 321 cells for $24 \mathrm{hr}$ was $35.1 \mu \mathrm{g} / \mathrm{mL}$. This result agreed with Attarde and Pandit (2017) who reported that Purified toxins from snake venoms was showed cytotoxic activity against $M C F-7(\mathrm{ER}+)$ and $M D A-$ $M B-231$ (ER-) cells via dose dependent manner. Also, Ravi et al. (2018) assured that the proapoptotic action of PLA2 isolated from snake venom towards leukemia cells, and explained that the cytotoxic mechanism of PLA2 are poorly under stood, this enzyme class directly act on the membrane phospholipid metabolism and interfere with lipid biosynthesis in tum- or cell line. Another possibility was that PLA2 triggers the production of reactive oxygen species and induces oxidative stress that associated with the cytotoxic effects (Marcussi et al, 2013). Depending on these results, that $C v$ venom was more toxic and potent than P1A2 fraction.

In the present study, cell cycle arrest of MDA321 treated $C v$ venom was observed in $\mathrm{G} 2 / \mathrm{M}$ cell during incubation entering the subsequent stage and interrupted at this point. Thus, the anti-proliferative activity of the venom was detected which block cell growth in G2/M and induced apoptosis during Pre-G1. This result agreed with Gomes et al. (2010) and Chaisakul et al. (2017) who reported that the snake venom cytotoxins have an effect on targeting cancer cell proliferation, migration, invasion, neovasculari- zation and apoptotic activity through arresting cell cycle in Pre-G1 population. But, this result disagreed with Gomes (2015) who showed that the Russell's viper venom arrested cell cycle in G1/S phase on leukemic U937 cancer cells after $24 \mathrm{hr}$ of treatment. This difference may be due to species difference and/or cell line used. Apoptosis of $C v$ venom was represented in early and late apoptosis as well as necrosis. This agreed with Ebrahim et al. (2014) who reported that MCF-7 cell lines treated with Cobra venom showed early apoptotic and late apoptotic as well as necrosis. This result may be explained by cytotoxicity of snake venom that targeted to cellular metabolism alterations and affected on cancerous cells by blocking of some specific ion channels, inhibiting angiogenesis and activating intracellular pathways causing apoptosis (Calderon et al, 2014; Ebrahim et al, 2016). Rahman and Choudhary (2015) reported that Viperistatin derived from Vipera venom has characterized a KTS motified in the integrin active binding site loop leading to block the $\alpha 1 \beta 1$ integrin. Thus, the antiangiogenic cyclic KTS peptides were induced the blockage of the binding of $\alpha 1 \beta 1$ and $\alpha 2 \beta 1$ integrins.

In the present study, cell cycle arrest of MDA321 treated PLA2 showed that G2/ M cell during incubation entering the subsequent stage and interrupted at this point. As a result, the anti-proliferative activity of the venom was detected which block cell growth in G2/M and then induced apoptosis during Pre-G1. Apoptosis of the PLA2 venom was represented in early and late apoptosis as well as necrosis, but was lower than $C v$ and stander drug. Chaisakul et al. (2016) found that other active components of snake venom such as PLA2 have the potential of anticancer effects. PLA2 was induced apoptosis in various cancer types such as breast adenocarcinoma, human leukemia $\mathrm{T}$ and $\mathrm{Er}$ lich ascetic tumor cell line. Omran (2003) reported that apoptosis included a cascade of cytoplasmic and nuclear events have been resulted in a series of morphological chang- 
es and eventually cause cell demise through a variety of different stimuli. On the other hand, necrosis resulted in cell lysis and extensive damage to surrounding tissues by physical damage or oxygen starvation. Viability of the most sensitive cancer cell type was reduced upon exposure to the PLA2cells and to some extent also to PLA2s from the $V$. lebetina and $N$. naja oxiana (Khannoon et $a l, 2016)$. There was no inhibitory effect of all $S v$ PLA2 preparations towards LNCaP cells and low inhibitory effect $(8 \%-20 \%)$ towards the PC-3, MCF-7 and B10-F16 cells (Samel et al, 2013).

In the present study, apoptosis and cell cycle arrest of MDA321 treated cisplatin showed G2/M cell during incubation entering the subsequent stage and interrupted at this point. The anti-proliferative activity of the venom was detected which block cell growth in G2/M and then induced apoptosis during Pre-G1. Cisplatin represents in early and late apoptosis as well as necrosis, these results nearly as C.v., but gave more necrosis than our tested venom and fraction. This result agreed with Shaloam and Paul Bernard (2014) who explained that the mode of action was linked to its ability to crosslink with purine bases on the DNA; interfering with DNA repair mechanisms, causing DNA damage, and subsequently inducing apoptosis in cancer cells. There were two major pathways of the apoptotic cell death (Kischkel et al, 1995).

In the present study, Caspase $3,8, \& 9$ showed gene expression level of effector gene as Caspase 3 on MDA321 cell line after treatment with $\mathrm{IC}_{50}$ of C.v. venom by RealTime PCR. Al-Sadoon et al. (2012) reported that Caspase-3 gene up regulation was detected in the treated MCF-7 with Xanthina venom. Thus, the two studies agreed as the results evaluate the up regulation of Capsase-3 gene in breast cancer cell lines treated with snake venoms leading to induce apoptosis. They added that induction of cell-cycle arrest in breast cancer cell lines was reported via caspase-dependent apoptosis by the sna- ke venoms and their active compounds. The expression of active Caspase- 3 was increaseed in MDA-MB-231 \& MCF-7 breast cancer cells treated with snake venom. Animal venoms can alter the gene expression and increase the expression of pro-apoptotic proteins (Chaisakul et al, 2016). According to Calderon et al. (2014) snake toxins can increase the expression of pro-apoptotic proteins. PLA2 causing the lowest upregulation effect on caspase-3. This result agreed with Ravi et al. (2018) who explained that the loss of mitochondrial membrane potential and caspase 3 activations, and thus PLA2 induce apoptosis; also activation of caspase $3, \& 9$ confirmed the pro-apoptotic action of this toxin. Concerning Caspase $8, \&$ caspase 9 , showed that the gene expression level of theses initiator genes on MDA321 cell line after the treatment with the IC50 of venom using Real-Time PCR. Snake toxins can induce apoptosis via ROS-independent mitochondrial dysfunction pathway and the caspase-dependant mechanism (Calderon et al, 2014; Ebrahim et al, 2016). Moreover, the snake cytotoxins can contribute apoptosis mediating via cleaving poly (ADP-ribose) polymerase (PARP) (Gomes et al, 2010). Also, LAAOs of $C v$ stimulate apoptotic activity through the oxidative reaction mediated by releasing $\mathrm{H}_{2} \mathrm{O}_{2}$ in the oxidation process of the enzyme and causing alteration of gene expression that leading to trigger apoptosis (Gomes et al, 2010). Chaisakul et al. (2016) isolated LAAO from venom is exhibited a specific anticancer activity on human breast adenocarcinoma cell line by both extrinsic and intrinsic pathways leading to enhance the activities of caspase- 8 \& caspase9 and then induce cell apoptosis. MDA-MB231 cells treated with the PLA2 inhibitor from Viper venom show the lowest effect on caspase $8 \&$ caspase 9 , these results may be due to loss of mitochondrial membrane potential and caspase 3 activations. Thus, PLA2 induced apoptosis, and also activation of caspase 3 , \& 9 confirmed the pro-apoptotic action of this toxin (Ravi et al, 2018). MDA- 
MB-231 cells treated with cisplatin showed lower effect than $C v$ on caspase $3,8 \& 9$. This agreed with Shalaom and Paul (2014) who reported that the presence of two major pathways of apoptotic cell death. The extrinsic pathway was initiated when ligands bind to the tumor necrosis factor- $\alpha$ (TNF $\alpha$ ) receptor super family followed by oligomerization and recruitment of procaspase- 8 via adaptor molecules to form the death-inducing the signaling complex (Kischkel et al, 1995). The intrinsic pathway was initiated by cellular stress, such as DNA damage, resulting in release of cytochrome-c from the mitochondria causing activation of procaspase- 9 via the interaction with apoptosis promoting activating factor-1 (APAF-1) and formation of an active apoptosome complex. Bcl-2 family proteins regulate DNA damage-induced apoptosis by regulating the release of mitochondrial cytochrome $\mathrm{c}$ in response to DNA damage. Cisplatin-induced genotoxic stress activa-ted the multiple signal transduction pathways, which can contribute to apoptosis or chemo resistance.

\section{Conclusion}

The outcome data proved that Cerastes vipera venom possesses anti-cancer potential on human breast cancer in comparison with Cisplatin drug. This positively related to the cell cycle arrest and apoptotic induction as well as apoptotic gene expression.

\section{Recommendations}

1- More cancer cell lines must be tested for verification of anti-cancer potentials of target test materials. 2- In vivo application of anti-cancer potentials of tested materials using murine models. 3- Monitoring of biochemical changes pre and post treatment with anti-cancer agent regarding the antiloxidant parameters (GTH, MDA, NO, ROS etc.).

\section{References}

Abdel-Aziz SAA, Mohamed AF, Zahkouk S AM, Ali RAM, 2017: Evaluation of anticancer activity of some venomous animal toxins on human breast and colon cancer cell lines and related antioxidant profile. Inter. J. Adv. Res. 5, 2:2036-53.

Al-Sadoon, MK, Abdel-Maksoud, MA, Rabah, DM, Badr, G, 2012: Induction of apoptosis and growth arrest in human breast carcinoma cells by a snake (Walterinnesia aegyptia) venom combined with silica nanoparticles: crosstalk between Bcl2 and caspase 3. Cell. Physiol. Biochem. 30, 3:653-65.

Alyan, MS, Shalaby, MA, El-Sanousi, AA, Fahmy, A, El-Sayed, M, et al, 2014: Antiviral and anticancer potentials of snake and scorpion venom derivatives. Invent. Rapid. Mol. Pharmacol. 2:1-11.

Attarde, SS, Pandit, SV, 2017: Cytotoxic activity of NN-32 toxin from Indian spectacled cobra venom on human breast cancer cell lines. BMC Complement, Alter Med. 17, 1: 503-8.

Bradshaw, MJ, Saviola, AJ, Fesler, E, Mackessy, SP, 2016: Evaluation of cytotoxic activities of snake venoms toward breast (MCF-7) and skin cancer (A-375) cell lines. Cytotechnology 68, 4:687-700.

Leonardo, A, Calderon, JC, Sobrinho, KD, Zaqueo, AA, et al, 2014: Antitumoral activity of snake venom proteins: new trends in cancer therapy. Hindawi Publishing Corporation BioMed Res. Inter. V. 2014, Article ID 203639, 19 pages http://dx.doi.org/10.1155/ 203639.

Chaisakul, J, Hodgson, WC, Kuruppu, S, Prasongsook, N, 2016: Effects of animal venoms and toxins on hallmarks of cancer. J. Cancer 7, 11:1571-8.

Chaisakul, J, Rusmili, MRA, Hodgson, WC, Hatthachote, P, Suwan, K, et al, 2017: A pharmacological examination of the cardiovascular effects of Malayan krait (Bungarus candidus) venoms. Toxins 9, 4:122-8.

Cummings, BS, Lasker, JM, Lash, LH, 2000: Expression of glutathione-dependent enzymes and cytochrome P450s in freshly isolated and primary cultures of proximal tubular cells from human kidney. J. Pharmacol. Exp. Therap. 293, 2:677-85.

Cummings, B.S, McHowat, J, Schnellmann, R G, 2000: Phospholipase A2s in cell injury and death. J. Pharmacol. Exp. Therap. 294, 3:793-9. Ebrahim, K, Shirazi, FH, Vatanpour, H, Kobarfard, F, Rabiei, H, 2014: Anticancer activity of cobra venom polypeptide, cytotoxin-II, against human breast adenocarcinoma cell line (MCF-7) via the induction of apoptosis. J. Brea. Cancer 17, 4:314-22. 
Ebrahim, K, Vatanpour, H, Zare, A, Shirazi, FH, Nakhjavani, M, 2016: Anticancer activity a of caspian cobra (Naja Naja oxiana) snake venom in human cancer cell lines via induction of apoptosis. Iranian J. Pharm. Res. IJPR, 15:S1016.

Gomes, A, Bhattacharjee, P, Mishra, R, Biswas, KA, Dasguta, CS, et al, 2010: Anticancer potential of animal venoms and toxins. Indian J. Exp. Biol. 48:93-103.

Gomes, A, Biswas, AK, Bhowmik, T, Saha, P P, Gomes, A, 2015: Russell's Viper venom purified toxin Drct-II inhibits the cell proliferation and induces g1 cell cycle arrest. Transl. Med. 5, 153:1025-61.

Khannoon, ER, Rupik, W, Lewandowski, D, Dubińska-Magira, M, Swadźba, E, et al, 2016: Unique features of myogenesis in Egyptian cobra (Naja haje) (Squamata: Serpentes: Elapidae). Protoplasma 253, 2:625-33.

Kischkel, FCl, Hellbardt, S, Behrmann, I, Germer, M, Pawlita, M, et al 1995: Cytotoxicitydependent APO-1 (Fas/CD95)-associated proteins form a death-inducing signaling complex (DISC) with the receptor. EMBO. J. 14:5579-88. Marcussi, S, Stábeli, RG, Santos-Filho, NA, Menaldo, DL, Pereira, LLS, et al 2013: Genotoxic effect of Bothrops snake venoms and isolated toxins on human lymphocyte DNA, Toxicon 65:9-14.

Omran, MAA, 2003: In vitro anticancer effect of scorpion Leiurus quinquestriatus and Egyptian Cobra venom. J. Med. Sci. 3:66-86.
Rahman, A, Choudhary, MI, 2015: Anti-Angiogenesis Drug Discovery and Development. Amsterdam, Elsevier Science.

Ravi Kant Upadhyay, 2018: Use of Animal Venom Peptides/Toxins in Cancer Therapeutics: Mini Review. Curr. Trends Biomed. Eng. Biosci. 16:4-18.

Rodrigues, RS, Izidoro, LFM, De Oliveira, J R, Robson, J, Sampaio, SV, et al 2009: Snake venom phospholipases A2: a new class of antitumor agents. Prot. Pept. Lett. 16, 8:894-8.

Salvesen, GS, Abrams, J.M, 2004: Caspase activation-stepping on the gas or releasing the brakes? Lessons from humans and flies. Oncogene 23:16:2774-8.

Salvesen, GS, Dixit, VM, 1997: Caspases, intracellular signaling by proteolysis. Cell 91, 4: 443-6.

Samel, M, Vija, H, Kurvet, I, Künnis-Beres, $\mathrm{K}$, Trummal, $\mathrm{K}$, et al, 2013: Interactions of PLA2-s from Vipera lebetina, Vipera berus berus and Naja naja oxiana venom with platelets, bacterial and cancer cells. Toxins 5, 2: 203-23.

Yalcin, HT, Ozen, MO, Gocmen, B, Nalbantsoy, A, 2014: Effect of Ottoman viper (Montivipera xanthina (Gray, 1849) venom on various cancer cells and on microorganisms. Cytotechnology 66, 1:87-94.

WHO, 2018: Latest global cancer data. Geneva, Switzerland, Press release $\mathrm{N}^{\circ} 263$.

Zouari-Kessentini, R, Srairi-Abid, N, Bazaa, A, El Ayeb, M, Luis, J, et al, 2013: Antitumoral potential of Tunisian snake venoms secreted phospholipases Bio-Med Res. Int. 2013; 2013: 391389. doi: 10.1155/2013/ 391389

\section{Explanation of figures}

Fig. 1: Determination of cytotoxicity (IC50) of Cerastes vipera venom, PLA2, and Cisplatin.

Fig. 2: Determination of cell cycle analysis under the effect of C. vipera venom, PLA2, and Cisplatin compared with control MDA-MB-231 cells.

Fig. 3: Determination of total, early \&late apoptosis as well as necrosis under effect of $C$. vipera venom, PLA2m and Cisplatin com-pared with control MDA-MB-231 cells.

Fig. 4: Gene expression level of casp 3 under effect of $C$. vipera venom, PLA2 \&Cisplatin compared with control MDA-MB-231 cells.

Fig. 5: Gene expression level of casp 8 under effect of $C$. vipera venom, PLA2 \&Cisplatin compared with control MDA-MB-231 cells.

Fig. 6: Gene expression level of casp 9 under effect of $C$. vipera venom, PLA2 \&Cisplatin compared with control MDA-MB-231 cells. 

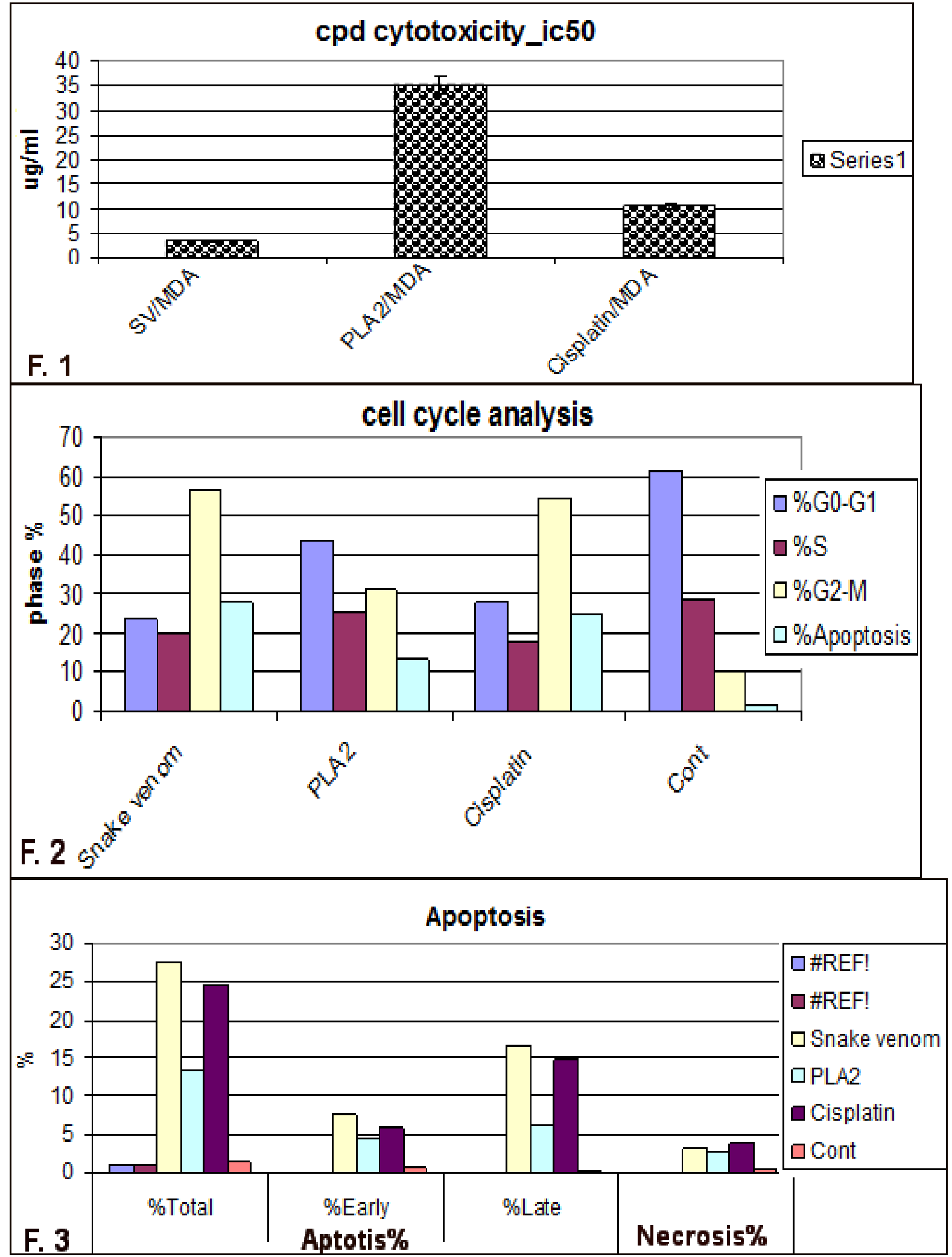

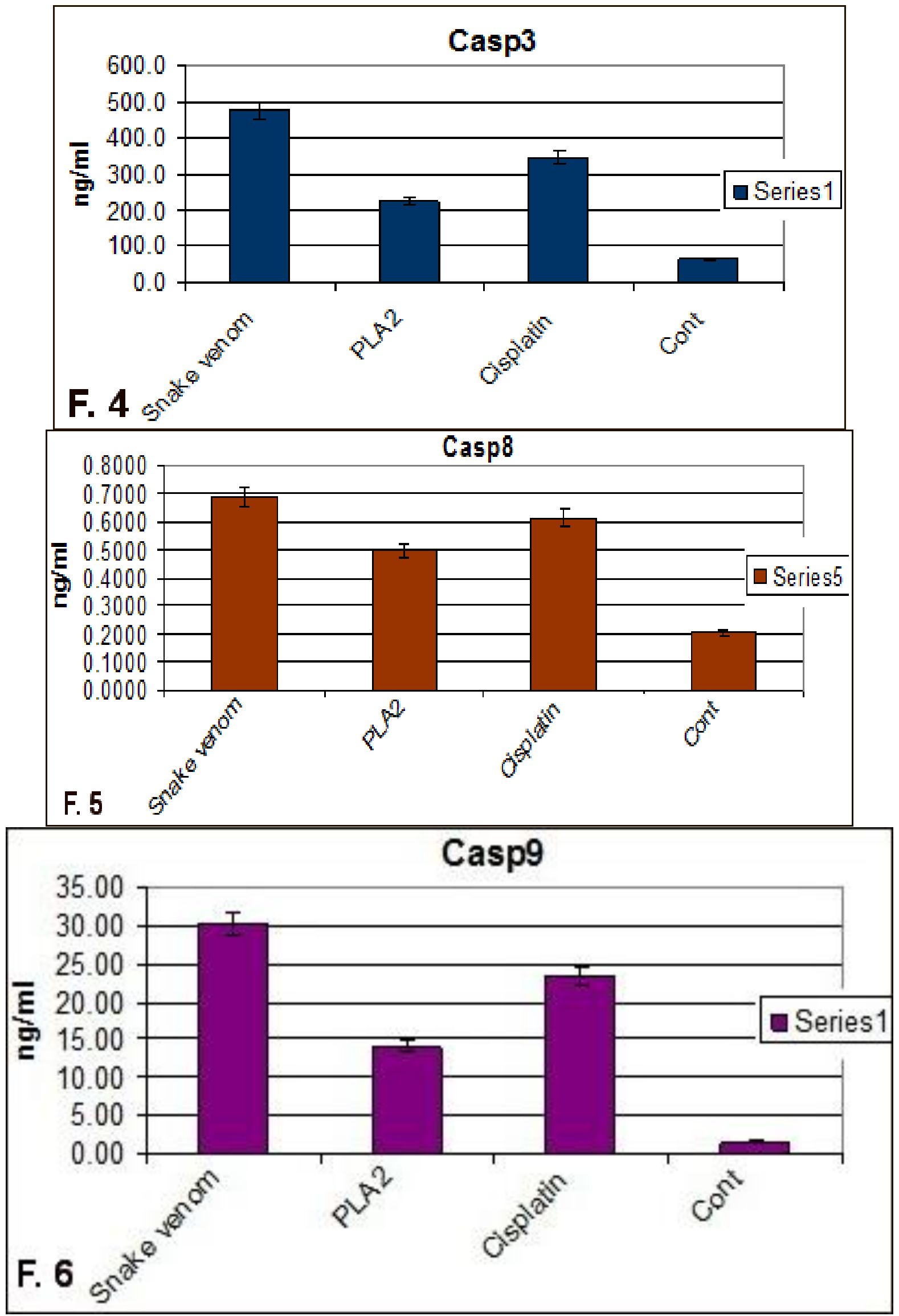